\title{
Differences between amyloid toxicity in alpha and beta cells in human and mouse islets and the role of caspase-3
}

\author{
E. Law • S. Lu • T. J. Kieffer • G. L. Warnock • Z. Ao • \\ M. Woo • L. Marzban
}

Received: 12 November 2009 / Accepted: 10 February 2010/Published online: 6 April 2010

(C) Springer-Verlag 2010

\begin{abstract}
Aims/hypothesis Type 2 diabetes is characterised by decreased beta cell mass and islet amyloid formation. Islet amyloid formed by aggregation of human islet amyloid polypeptide (hIAPP) is associated with beta cell apoptosis. We used human and transgenic mouse islets in culture to examine whether deletion of caspase-3 protects islets from apoptosis induced by endogenously produced and exogenously applied hIAPP and compared hIAPP toxicity in islet alpha and beta cells.

Methods Human and wild-type or caspase-3 knockout mouse islet cells were treated with hIAPP. Rat insulinoma INS-1 cells were similarly cultured with hIAPP and the
\end{abstract}

Electronic supplementary material The online version of this article (doi:10.1007/s00125-010-1717-9) contains supplementary material, which is available to authorised users.

E. Law $\cdot$ S. Lu $\cdot$ L. Marzban $(\bowtie)$

Division of Pharmacology and Toxicology,

Faculty of Pharmaceutical Sciences,

University of British Columbia,

2146 East Mall,

Vancouver, BC V6T 1Z3, Canada

e-mail: marzban@interchange.ubc.ca

\section{T. J. Kieffer}

Department of Cellular and Physiological Sciences,

Faculty of Medicine, University of British Columbia,

Vancouver, BC, Canada

T. J. Kieffer · G. L. Warnock $\cdot$ Z. Ao

Department of Surgery, Faculty of Medicine,

University of British Columbia,

Vancouver, BC, Canada

\section{Woo}

Department of Medicine, University of Toronto,

Ontario Cancer Institute, St Michael's Hospital,

Toronto, ON, Canada amyloid inhibitor Congo Red or caspase-3 inhibitor. Human and hIAPP-expressing caspase-3 knockout mouse islets were cultured to form amyloid fibrils and assessed for beta and alpha cell apoptosis, beta cell function and caspase-3 activation.

Results hIAPP-treated INS-1 cells had increased caspase-3 activation and apoptosis, both of which were reduced by inhibitors of amyloid or caspase-3. Similarly, hIAPP-treated human and mouse islet beta cells had elevated active caspase-3- and TUNEL-positive cells, whereas mouse islet cells lacking caspase-3 had markedly lower beta cell but comparable alpha cell apoptosis. During culture, human islets that formed amyloid had higher active caspase-3- and TUNEL-positive beta cells than those without detectable amyloid. Finally, cultured hIAPP-expressing mouse islets lacking caspase-3 had markedly lower beta cell apoptosis than those expressing caspase-3, associated with an increase in islet beta cell/alpha cell ratio, insulin content and glucose response.

Conclusions/interpretation Prevention of caspase-3 activation protects islet beta cells from apoptosis induced by fibrillogenesis of endogenously secreted and exogenously applied hIAPP. Islet beta cells are more susceptible to hIAPP toxicity than alpha cells cultured under the same conditions.

Keywords Alpha cell apoptosis · Amylin · Amyloid .

Beta cell apoptosis - Caspase-3 - Islet amyloid polypeptide . Type 2 diabetes
Abbreviations
DMSO Dimethyl sulfoxide
ER Endoplasmic reticulum
HFIP 1,1,1,3,3,3-Hexafluoro-2-propanol
hIAPP Human islet amyloid polypeptide
rIAPP Rat islet amyloid polypeptide 


\section{Introduction}

Type 2 diabetes is characterised by progressive beta cell dysfunction, decreased beta cell mass, and islet amyloid deposition [1-5]. Islet amyloid formation caused by aggregation of human islet amyloid polypeptide (hIAPP, amylin) $[6,7]$ is associated with beta cell apoptosis and contributes to progressive beta cell death in type 2 diabetes [3-5]. Interestingly, islet amyloid also forms in human islets during culture [8] and following transplantation into mouse models of type 1 diabetes [9]. Importantly, widespread amyloid deposition was recently reported in human islets that had been transplanted into a type 1 diabetic patient [10].

hIAPP, the major component of islet amyloid, is a beta cell peptide that is co-localised and co-secreted with insulin in response to beta cell secretagogues [11-13]. It is not clear why normally soluble hIAPP molecules form toxic aggregates in type 2 diabetes. It has been proposed that the presence of an amyloidogenic sequence in the hIAPP molecule [14, 15], elevated hIAPP production/secretion from beta cells associated with increased insulin demand $[13,15]$, and defects in trafficking/processing of proIAPP because of beta cell dysfunction [16-18] all contribute to hIAPP aggregation in type 2 diabetes.

Previous in vitro studies have suggested different mechanisms for hIAPP toxicity, including formation of non-selective ion channel-like structures [19-23], activation of the caspase pathways [24, 25], and interaction of hIAPP fibrils with components of beta cell membranes, such as heparan sulphate proteoglycan [26, 27] or touch receptors [28]. It is, however, not clear which of these mechanism(s) contribute to hIAPP-induced beta cell death in primary islets, in which the level of endogenously produced hIAPP $(\mathrm{pmol} / \mathrm{l})$ is several fold lower $[4,29]$ than that used in vitro $(\mu \mathrm{mol} / \mathrm{l})$. Recent studies using transgenic rodents have demonstrated that endoplasmic reticulum (ER) stress caused by formation of intracellular hIAPP fibrils [30, 31] and oxidative stress [32] also contribute to cytotoxic effects of hIAPP. It therefore appears that, at least in vitro, hIAPPinduced beta cell apoptosis involves different mechanisms, although these mechanisms may share the same apoptotic signalling pathways. Also, the apoptotic effects of hIAPP on islet alpha cells and their potential differences from beta cells have yet to be studied.

Caspase-3 is the key downstream enzyme in the three major identified apoptotic pathways including: (1) mitochondrial (or intrinsic) initiated through cell stress, such as mitochondrial dysfunction, oxygen free radicals, metabolic toxins and anoxia; (2) cell death receptor (or extrinsic) initiated by activation of cell membrane death receptors such as Fas; and (3) ER stress initiated by misfolding/ accumulation of proteins within the ER and Golgi apparatus [4, 33-35]. In this study, we used two ex vivo models of islet amyloid formation, cultured human islets and mouse islets expressing hIAPP but lacking caspase-3, as well as transformed and primary islet cells, to examine whether deletion of caspase-3 can protect islets from hIAPP aggregates derived from endogenously secreted and exogenously applied hIAPP. We also tested whether different susceptibility of islet beta and alpha cells to amyloid toxicity may contribute to better survival of islet alpha cells than beta cells, leading to selective beta cell death in conditions associated with islet amyloid formation such as type 2 diabetes, islet culture and transplantation.

\section{Methods}

Materials Thioflavin S, dithizone, BSA, Congo Red, HEPES buffer, 2-mercaptoethanol, sodium bicarbonate, poly-L-lysine, Triton X-100, dimethyl sulfoxide (DMSO), 1,1,1,3,3,3-hexafluoro-2-propanol (HFIP), Avertin and collagenase (type XI) were obtained from Sigma-Aldrich (Oakville, ON, Canada). RPMI-1640, FBS, penicillin, streptomycin, gentamicin, cell dissociation buffer enzymefree Hanks'-based, Ham's-F10, trypsin-EDTA, and Glutamax were from Invitrogen Canada (Burlington, ON, Canada). Synthetic hIAPP and rat IAPP (rIAPP) (1-37), caspase-3 inhibitor (z-DEVD-FMK) and pan-caspase inhibitor (z-VDFMK) were from Bachem (Torrance, CA, USA), and Alamar Blue dye from Biosource International (Camarilli, CA, USA). CMRL final wash/culture medium was from Mediatech (Hemdon, VA, USA).

Human islets Freshly isolated human islets from cadaveric pancreatic donors were provided by the Ike Barber Human Islet Transplantation Centre (Vancouver, BC, Canada) in accordance with approved procedures and guidelines of the Clinical Research Ethics Board of the University of British Columbia. Islets were hand-picked and purity was assessed by dithizone staining. Isolated islets (purity $~ 90 \%$ ) were cultured in non-adherent 24 well culture plates (50 islets per well) in CMRL (5.5 mmol/1 glucose) supplemented with $10 \%$ (vol./vol.) FBS, $50 \mathrm{U} / \mathrm{ml}$ penicillin, $50 \mu \mathrm{g} / \mathrm{ml}$ streptomycin and $50 \mu \mathrm{g} / \mathrm{ml}$ gentamicin in humidified $5 \%$ $\mathrm{CO}_{2} / 95 \%$ air at $37^{\circ} \mathrm{C}$ overnight to allow recovery and then cultured in $11.1 \mathrm{mmol} / 1$ glucose for 7 days.

Animals To generate mice producing hIAPP but lacking caspase-3, hemizygous transgenic mice producing hIAPP in their pancreatic beta cells $\left(\mathrm{h} I A P P^{+/-}\right)$were cross-bred with caspase-3 knockout mice $\left(\operatorname{Casp}^{-1-}\right)$. The offspring $\left(\mathrm{h} I A \mathrm{PP}^{+/-} / \mathrm{Casp}^{+/-}\right)$mice were bred together and the first generation of these breeders was used for the experiments. hIAPP-expressing mice were maintained by breeding hIAPP-expressing C57BL/6 mice from the VA Puget Sound 
Health Care System (kindly provided by S. Kahn, University of Washington, WA, USA) with DBA/2J mice (Jackson Laboratory, Bar Harbor, ME, USA). hIAPP-expressing mice form islet amyloid and develop diabetes in the presence of a predisposing factor such as high-fat diet [36]. $\operatorname{Casp}^{-/-}$mice were maintained by breeding $\operatorname{Casp}^{+/-}$ mice from the Ontario Cancer Institute [37]. Casp $^{-/-}$mice have reduced apoptosis, which is tissue- and stimulusspecific $[37,38]$ and have normal islet structure without any marked abnormality in islet baseline viability [39]. All animals were fed a diet containing 9\% (wt/wt) fat (Purina \#5021, LabDiet, Richmond, IN, USA). Animals were cared for in accordance with guidelines of the Canadian Council on Animal Care and the University of British Columbia.

Islet isolation and culture Animals were anaesthetised with Avertin $(0.02 \mathrm{ml} / \mathrm{g}$ body weight, i.p.) and killed by cervical dislocation. The abdominal cavity was opened and $2.5 \mathrm{ml}$ ice-cold collagenase (type XI, Sigma) in Hanks' solution without $\mathrm{CaCl}_{2}$ (final concentration: $525 \mathrm{U} / \mathrm{ml}$ ) was injected via the common bile duct. Harvested pancreases were incubated with collagenase/Hanks' solution $(525 \mathrm{U} / \mathrm{ml})$ at $37^{\circ} \mathrm{C}$ for $12.5-14 \mathrm{~min}$ in a shaker water-bath $(120 \mathrm{rpm})$. Digestion was stopped by addition of ice-cold Hanks' containing $1 \mathrm{mmol} / \mathrm{CaCl}_{2}$. Digested pancreatic tissues were rinsed with the same solution, resuspended in Ham'sF10 supplemented with $0.5 \%$ (wt/vol.) BSA, penicillin $(50 \mathrm{U} / \mathrm{ml})$ and streptomycin $(50 \mu \mathrm{g} / \mathrm{ml})$, and filtered through a $70 \mu \mathrm{m}$ nylon mesh cell strainer (BD Biosciences, Oakville, ON, Canada). Isolated islets were hand-picked (purity $>95 \%$ ) and cultured in Ham's-F10 (16.7 mmol/l glucose) for 7 days.

Dispersion of islets Human or mouse islets ( 300) were dispersed in $150 \mu$ l dissociation buffer by gently pipetting up and down for $1 \mathrm{~min}$ followed by a 1 min rest repeated for a total of $5 \mathrm{~min}$. Then $2 \mu \mathrm{l}$ trypsin-EDTA $(0.25 \%)$ and $1 \mu$ l DNase I $(0.4 \mathrm{mg} / \mathrm{ml})$ were added and dissociation continued for $1 \mathrm{~min}$ and stopped by adding $150 \mu \mathrm{l}$ medium (CMRL: human islets; Ham's-F10: mouse islets). Cells were centrifuged $\left(500 \times \mathrm{g}, 5 \mathrm{~min}, 4^{\circ} \mathrm{C}\right)$ and cell pellets were resuspended in $100 \mu \mathrm{l}$ culture medium. Cell viability was assessed by Trypan Blue and cells were cultured in poly-Llysine-coated plates in CMRL (human) or Ham's-F10 (mouse) containing 5.5 and $10 \mathrm{mmol} / \mathrm{l}$ glucose, respectively.

Transformed cell lines INS-1 (832/13) cells, a transformed rat beta cell line, and beta-TC 3 and alpha-TC cells, mouse beta and alpha cell lines, respectively, were gifts from $\mathrm{C}$. Newgard (Duke University Medical Center, NC, USA) and P. Halban (University of Geneva, Switzerland). Cells were grown in RPMI-1640 (INS-1) or DMEM (beta-TC3 and alpha-TC) containing 11.1 and $5.5 \mathrm{mmol} / \mathrm{l}$ glucose, respective- ly, supplemented with $10 \%$ (vol./vol.) FBS, $50 \mathrm{U} / \mathrm{ml}$ penicillin, $50 \mu \mathrm{g} / \mathrm{ml}$ streptomycin and $50 \mu \mathrm{mol} / 1$ 2-mercaptoethanol (INS-1).

Alamar Blue reduction assay For assessment of cell viability, cells were incubated with Alamar Blue dye diluted 1:10 in medium for $3 \mathrm{~h}$ at $37^{\circ} \mathrm{C}$. Fluorescence of control (blank) and samples were read (excitation: 530; emission: $590 \mathrm{~nm}$ ) using a Fluoroskan Ascent plate reader (Thermo Labsystems, Helsinki, Finland) and data calculated as per cent of control.

Treatment with hIAPP, Congo Red or caspase inhibitors Lyophilised hIAPP or rIAPP was dissolved in HFIP and incubated at room temperature for $1 \mathrm{~h}$; aliquots were frozen $\left(-80^{\circ} \mathrm{C}\right)$, lyophilised and kept $\left(-20^{\circ} \mathrm{C}\right)$ until used. Stock hIAPP or rIAPP solutions were prepared freshly for each experiment by dissolving lyophilised aliquots in culture medium and added to INS-1 or dispersed islet cells, then cultured for different time points as detailed in figure legends. Stock Congo Red solution was prepared in DMSO, diluted in culture medium and added to cell cultures at a final concentration of $25 \mu \mathrm{mol} / 1$ before addition of hIAPP. Caspase-3 (z-DEVD-FMK) or pancaspase (z-VD-FMK) inhibitors were added to cell cultures at a final concentration of $100 \mu \mathrm{mol} / \mathrm{l} 1 \mathrm{~h}$ before addition of hIAPP.

TUNEL, thioflavin S and immunolabelling Paraffin-embedded islet or pancreatic sections were dewaxed, rehydrated and blocked in $2 \%$ (vol./vol.) normal goat or donkey serum (Vector Laboratories, Burlingame, CA, USA). For insulin (or glucagon) and TUNEL staining, fixed cells or histological sections (following antigen retrieval with citrate buffer) were incubated with guinea pig anti-insulin or rabbit antiglucagon antibody (Dako, Carpinteria, CA, USA) at a 1:100 dilution at $4^{\circ} \mathrm{C}$ overnight, followed by incubation with Alexa Fluor 488-conjugated goat anti-guinea pig (or anti-rabbit) antibody (Molecular Probes, Eugene, OR, USA) for $1 \mathrm{~h}(1: 100)$ at room temperature and TUNEL reaction mixture (Roche Diagnostics, Laval, QC, Canada) for $30 \mathrm{~min}\left(37^{\circ} \mathrm{C}\right)$. For insulin and active caspase-3 immunostaining, cells or islet/tissue sections (following antigen retrieval) were incubated with anti-insulin and Texas Red-conjugated goat anti-guinea pig antibody (Jackson Laboratory) for $1 \mathrm{~h}$ (1:100, room temperature), followed by incubation with anti-cleaved caspase-3 antibody (Cell Signaling, Pickering, ON, Canada) overnight $\left(4^{\circ} \mathrm{C}, 1: 50\right)$ and Alexa 488-conjugated anti-rabbit antibody (Molecular Probes) for $1 \mathrm{~h}$ (1:100, room temperature). For insulin and glucagon immunolabelling, following insulin staining, sections were similarly incubated with rabbit anti-glucagon (Dako) and Alexa 488-conjugated goat anti-rabbit antibodies and for 
thioflavin S staining incubated with $0.5 \%$ (wt/vol.) thioflavin $\mathrm{S}$ solution for $5 \mathrm{~min}$. For quantification studies, sections were counterstained with the nuclear dye DAPI (Vector Laboratories).

Glucose-stimulated insulin secretion Cultured mouse islets were pre-incubated $(1 \mathrm{~h})$ in Krebs-Ringer bicarbonate (KRB) buffer containing $10 \mathrm{mmol} / \mathrm{l}$ HEPES (pH 7.4), $0.25 \%$ (wt $/ \mathrm{vol}$.) BSA and $1.67 \mathrm{mmol} / 1$ glucose at $37^{\circ} \mathrm{C}$ followed by $1 \mathrm{~h}$ incubation in KRB containing $1.67 \mathrm{mmol} / \mathrm{l}$ glucose (basal insulin release) and then $1 \mathrm{~h}$ incubation in the same buffer containing $16.7 \mathrm{mmol} / \mathrm{l}$ glucose (stimulated insulin release). Islets were lysed in $100 \mu \mathrm{l}$ lysis buffer containing $1 \mathrm{~mol} / \mathrm{l}$ acetic acid $/ 0.1 \%$ (wt/vol.) BSA followed by three times freeze-thawing. Incubation media and islet lysates were centrifuged and supernatant fractions were frozen $\left(-20^{\circ} \mathrm{C}\right)$ until assayed. Insulin levels were measured using a mouse-specific insulin ELISA kit (ALPCO Diagnostics, Salem, NH, USA). Islet insulin content was reported as percentage of insulin content in cultured wild-type islets taken as $100 \%$ and the magnitude of insulin response to elevated glucose was calculated as fold increase over basal insulin release.

Statistical analysis Data are expressed as means \pm SEM. Statistical analyses were performed using one-way ANOVA followed by a Newman-Keuls test or by a Student's $t$ test, as appropriate. $p<0.05$ was taken as significant. All experiments were performed in triplicate and repeated three to five times.

\section{Results}

hIAPP-induced activation of caspase-3 and apoptosis are prevented by the amyloid-binding dye Congo Red INS-1 beta cells were treated with different concentrations of synthetic hIAPP to determine the optimal concentration of exogenously applied hIAPP for induction of beta cell apoptosis. As expected [40, 41], exposure to fibrillogenic hIAPP significantly decreased the viability of INS-1 beta cells in a concentration-dependent manner (Fig. 1a). This was associated with a marked increase in the proportion of apoptotic cells (Fig. 1b). To test whether inhibition of hIAPP aggregation and its interaction with beta cells can prevent caspase-3 activation and apoptosis, cells were treated with hIAPP in the presence or absence of the amyloid-binding dye Congo Red at different time points. hIAPP (but not non-fibrillogenic rIAPP) markedly increased the number of active caspase-3-positive cells about $8 \mathrm{~h}$ following exposure, which was further increased at $16 \mathrm{~h}$ and remained elevated for $24 \mathrm{~h}$ (Fig. 1c; Electronic supplementary material (ESM) Fig. 1a). The effects of
hIAPP on caspase-3 activation were concentration dependent (ESM Fig. 2) and the time point of caspase-3 activation preceded that of apoptosis (Fig. 1d). Treatment with Congo Red markedly decreased the proportion of both active caspase-3- and TUNEL-positive cells in hIAPPtreated cells.

Exposure to hIAPP aggregates induces activation of caspase-3 and apoptosis in primary human and mouse islet beta cells To further validate the role of caspase- 3 in hIAPP-induced cytotoxicity in primary beta cells, freshly isolated mouse islets were dispersed into single cells and cultured with or without hIAPP. As expected, non-treated mouse islet cells had low numbers of active caspase-3- and TUNEL-positive beta cells. As with transformed beta cells, hIAPP treatment markedly increased the number of both active caspase-3- and TUNEL-positive islet beta cells, leading to lower beta cell/total islet cell ratio in hIAPPtreated islet cells compared with non-treated cells (Fig. 1e-g; ESM Fig. 1b). Similarly, exposure of cultured human islet cells to hIAPP markedly increased the proportion of active caspase-3- and TUNEL-positive beta cells, which was associated with a decrease in beta cell/total islet cell ratio (Fig. 1h-j; ESM Fig. 1b).

Islet beta cells are more susceptible than alpha cells to the cytotoxic effects of extracellular hIAPP aggregates To compare the susceptibility of islet alpha and beta cells to the cytotoxic effects of exogenously applied hIAPP, alphaTC and beta-TC3 cells or dispersed mouse islet cells were cultured under the same conditions with or without hIAPP (Fig. 2). Interestingly, hIAPP-treated alpha-TC cells (Fig. 2a) had a markedly higher survival rate than betaTC3 cells (Fig. 2b) at all hIAPP concentrations (10$40 \mu \mathrm{mol} / \mathrm{l})$. These findings were further validated in primary alpha and beta cells (Fig. 2c, d; ESM Fig. 3). The proportion of TUNEL-positive islet beta cells was significantly higher than TUNEL-positive islet alpha cells treated with the same concentrations of hIAPP, suggesting that primary beta cells are much more susceptible than alpha cells to amyloid toxicity induced by exogenously applied hIAPP.

Inhibition of caspase-3 activation markedly reduces hIAPPinduced beta cell apoptosis To examine whether suppression of caspase-3 activation will inhibit hIAPP-induced apoptosis, INS-1 beta cells were pre-treated with a caspase3 or pan-caspase inhibitor prior to hIAPP treatment. Inhibition of caspase- 3 activation markedly decreased the number of active caspase-3-positive and apoptotic cells in hIAPPtreated cells (Fig. 3a, b). The effects of the pan-caspase and caspase-3 inhibitors were almost comparable, suggesting that caspase- 3 is the key downstream caspase mediating the 
a

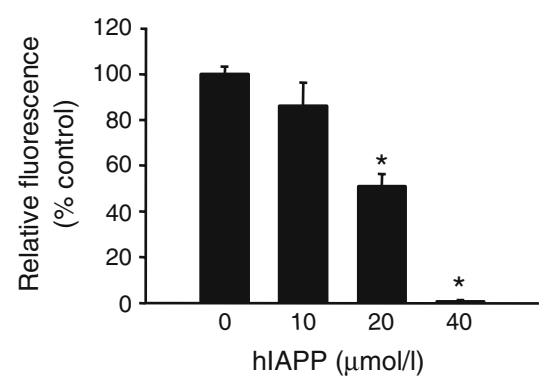

C

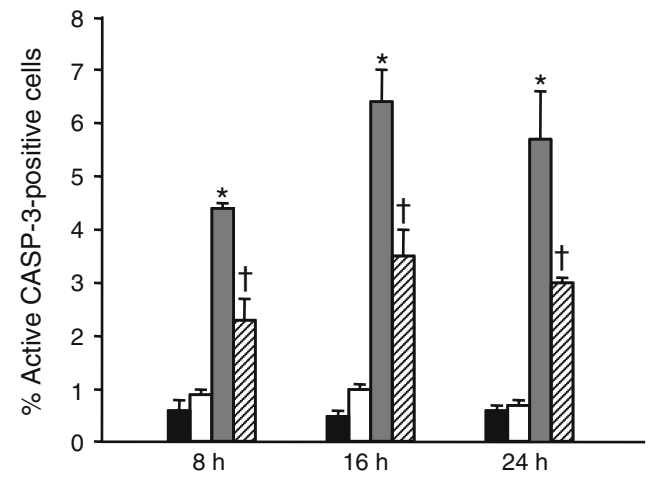

e

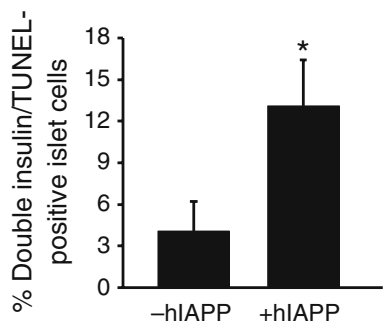

h

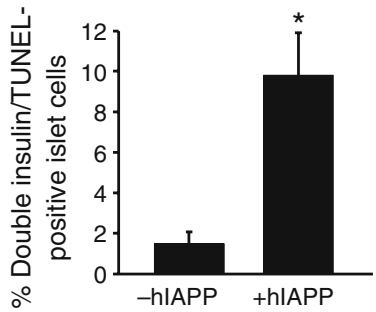

$\mathbf{f}$

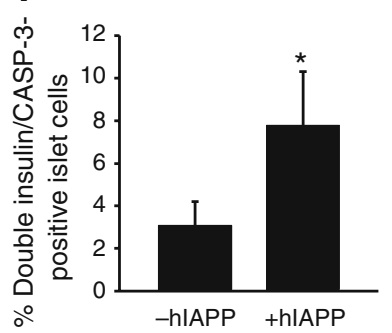

i

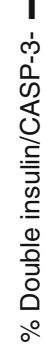

b

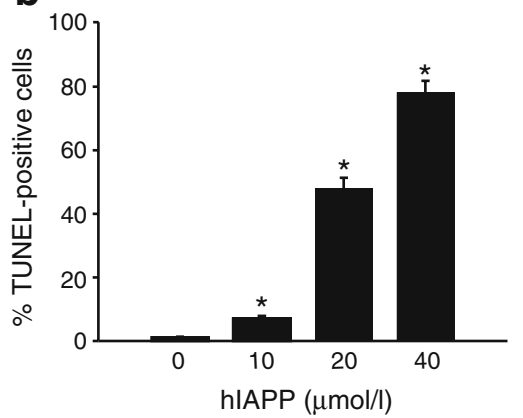

d

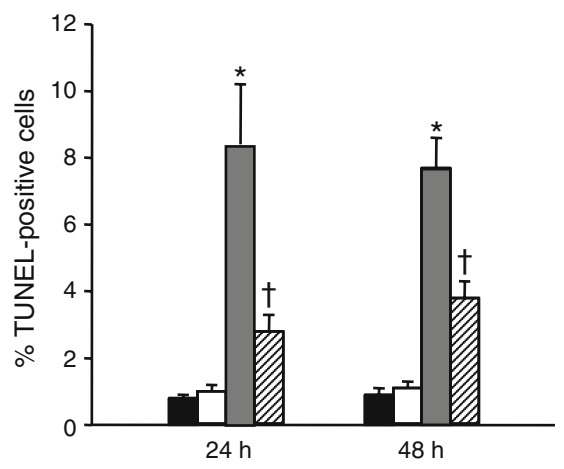

g

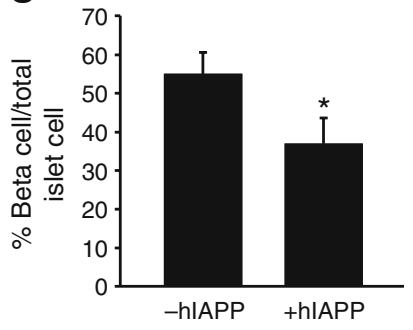

j

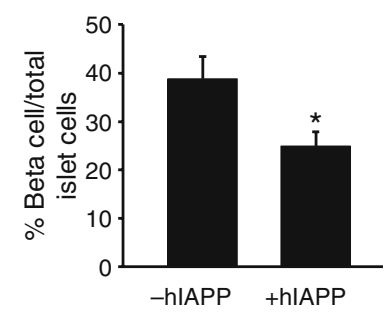

Fig. 1 Exogenously applied hIAPP induces caspase-3 activation and apoptosis in both transformed and primary islet cells. The amyloidbinding dye, Congo Red, markedly reduces hIAPP-mediated caspase3 activation and apoptosis. Cell viability (Alamar Blue) (a) and apoptosis (TUNEL-positivity) (b) were assessed in INS-1 beta cells cultured in the absence or presence of synthetic hIAPP $(10-40 \mu \mathrm{mol} / \mathrm{l}$, $24 \mathrm{~h}$ ). Proportion of cleaved (active)-caspase-3 (CASP-3)- (c) and TUNEL-positive INS-1 beta cells (d) treated with rIAPP (as control) or hIAPP $(10 \mu \mathrm{mol} / \mathrm{l})$ in the presence or absence of Congo Red $(25 \mu \mathrm{mol} / \mathrm{l})$ at different time points for up to $48 \mathrm{~h}$. Black bar, control; white bar, rIAPP; grey bar, hIAPP; white hashed bar, hIAPP+Congo Red. Proportion of double insulin- and TUNEL-positive cells in control and hIAPP-treated $(10 \mu \mathrm{mol} / \mathrm{l}, 24 \mathrm{~h})$ mouse (e) and human (h) islet cells. Proportion of double insulin- and active caspase-3-positive cells in control and hIAPP-treated mouse (f) and human (i) islet cells. Beta cell/total islet cell ratio in cultured mouse $(\mathbf{g})$ and human $(\mathbf{j})$ islet cells following culture with or without hIAPP. The proportion of apoptotic beta cells was quantified by manual counting of double insulin- and TUNEL- (or caspase-3-) positive cells in a minimum of ten microscopic fields each of 100-150 dispersed islet cells or 300 400 INS-1 cells. Beta/total islet cell ratio represents the mean of insulin-positive islet cells divided by total islet cells in each field. Results are expressed as means \pm SEM of three independent studies performed in triplicate. ${ }^{*} p<0.05$ vs non-treated control group; ${ }^{\dagger} p<$ 0.05 vs corresponding hIAPP-treated group (one-way ANOVA or Student's $t$ test) 

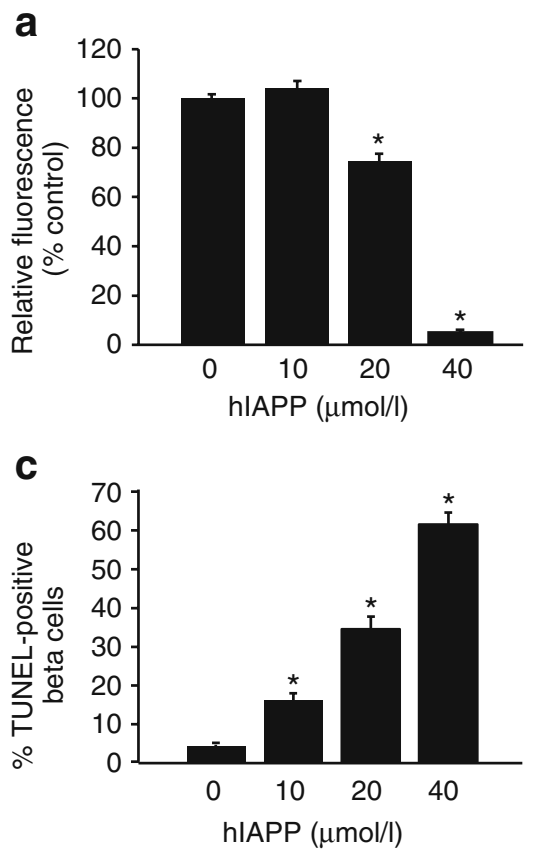

Fig. 2 Islet beta cells are more susceptible to the cytotoxic effects of extracellular hIAPP aggregates than alpha cells cultured under the same conditions. Mouse alpha-TC (a) and beta-TC3 (b) cells were cultured with different concentrations of fibrillogenic hIAPP (10$40 \mu \mathrm{mol} / \mathrm{l})$ for $24 \mathrm{~h}$. c, d Dispersed mouse islet cells were cultured in Ham's-F10 in poly-L-lysine-coated plates with or without hIAPP (10$40 \mu \mathrm{mol} / \mathrm{l}, 24 \mathrm{~h})$. The number of apoptotic alpha and beta cells were

toxic effects of hIAPP (Fig. 3b). To investigate whether the absence of caspase- 3 can protect primary islet beta cells from the cytotoxic effects of hIAPP, dispersed islet cells from wild-type and $\mathrm{Casp}^{-/-}$mice were cultured with or without hIAPP. hIAPP-treated islet cells from $\mathrm{Casp}^{-/-}$ mice had significantly lower beta cell apoptosis and higher beta cell/total islet cell ratio compared with wild-type (Fig. 3c-e). Treatment with non-fibrillogenic rIAPP did not have any detectable effect on caspase-3 activation or beta cell apoptosis in INS-1 or islet cells (ESM Fig. 4).

Deletion of caspase-3 in hIAPP-transgenic mouse islets prevents beta cell apoptosis induced by fibrillogenesis of endogenously expressed hIAPP and preserves beta cells during culture The absence of caspase-3 expression in $\mathrm{h} I A P P^{+} /$Casp $^{-/-}$mice was confirmed by genotyping PCR and double insulin and caspase-3 immunostaining of pancreatic sections (Fig. 4a). Freshly isolated islets from male and female hIAPP-transgenic mice (8-16 weeks) expressing or lacking caspase-3 were cultured in $16.7 \mathrm{mmol} / \mathrm{l}$ glucose (to potentiate amyloid formation) for 7 days. Islets from wild-type and $\operatorname{Casp}^{-/-}$mice with the same background, which do not express hIAPP, were cultured under similar conditions to detect any potential effects of elevated glucose on beta cell function/survival. Amyloid formation was comparable in islets from hIAPP- b

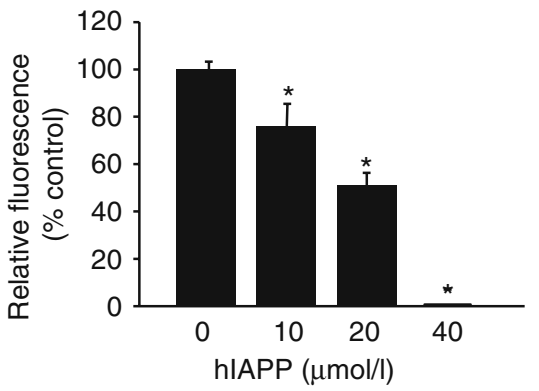

d

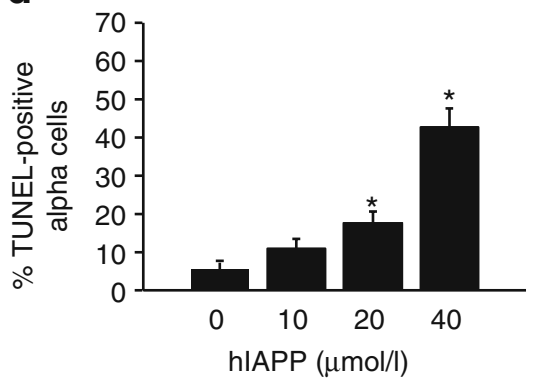

quantified by counting the number of double insulin- (or glucagon-) and TUNEL-positive islet cells in a minimum of ten microscopic fields, each of about $80-100$ dispersed islet cells. Results are expressed as means \pm SEM of three independent experiments performed in triplicate. ${ }^{*} p<0.05$ vs non-treated control group (one-way ANOVA)

transgenic mice lacking or expressing caspase-3 both in vivo (12-month-old) and in vitro following 7 day culture (Figs 4b-d). As expected [16], formation of hIAPP aggregates in cultured hIAPP-expressing mouse islets was associated with an increase in the number of TUNELpositive beta cells. Despite comparable amyloid formation, hIAPP-expressing islets lacking caspase-3 had significantly lower number of beta cells undergoing apoptosis compared with islets expressing hIAPP and caspase-3 (Figs 4c, e).

The number of apoptotic alpha cells is comparable in cultured hIAPP-transgenic mouse islets expressing or lacking caspase-3 Double TUNEL and glucagon immunostaining revealed that despite the increased beta cell apoptosis induced by hIAPP aggregates formed by endogenously secreted hIAPP in cultured islets, the proportion of apoptotic alpha cells remained low (Fig. 4c, f). Furthermore, the proportion of apoptotic alpha cells was comparable in hIAPP-transgenic islets expressing and lacking caspase-3, leading to decreased islet beta/alpha cell ratio in hIAPP-transgenic mouse islets expressing caspase- 3 compared with those lacking caspase-3 (Fig. 4g).

Reduced amyloid-induced beta cell death by deletion of caspase-3 in hIAPP-expressing mouse islets is associated with enhanced beta cell function during culture We 
a
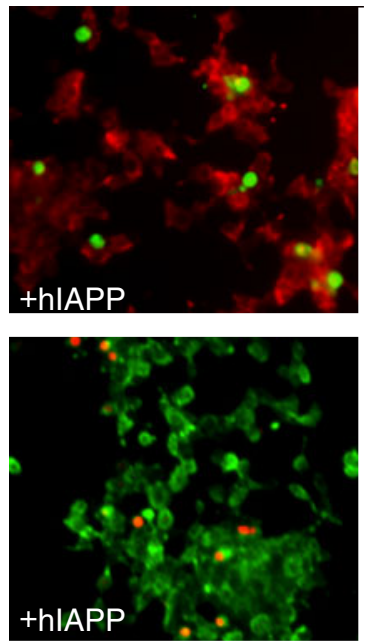

C
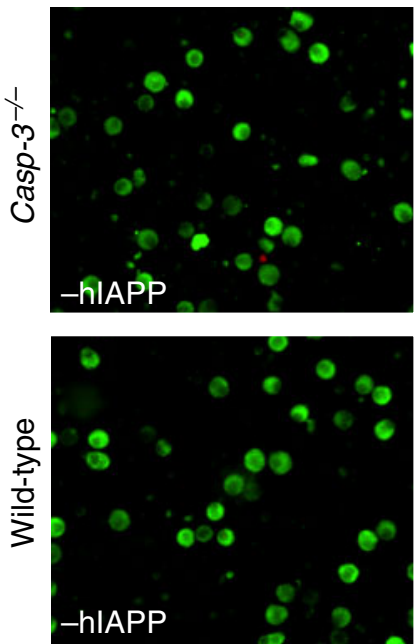
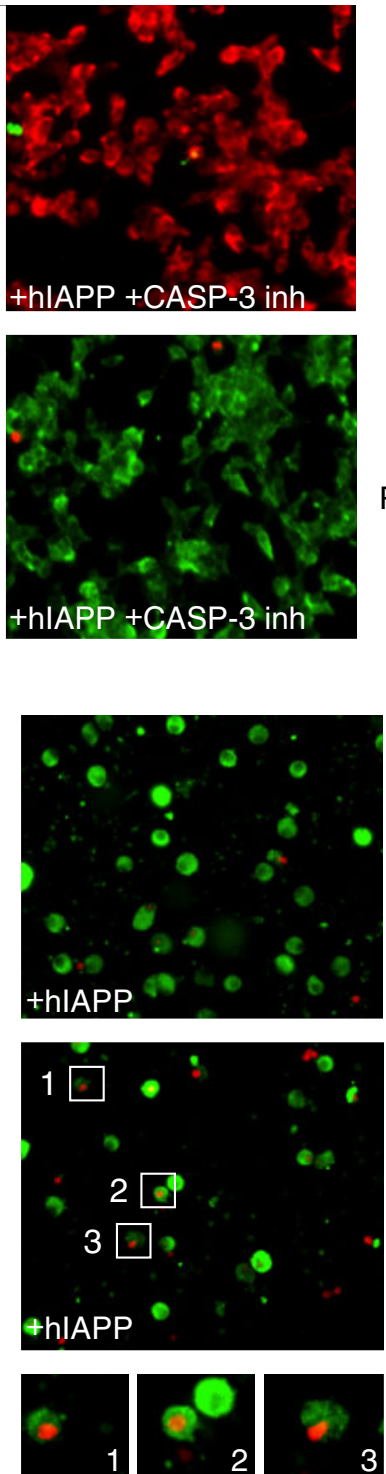

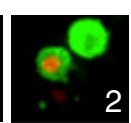

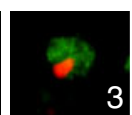

b

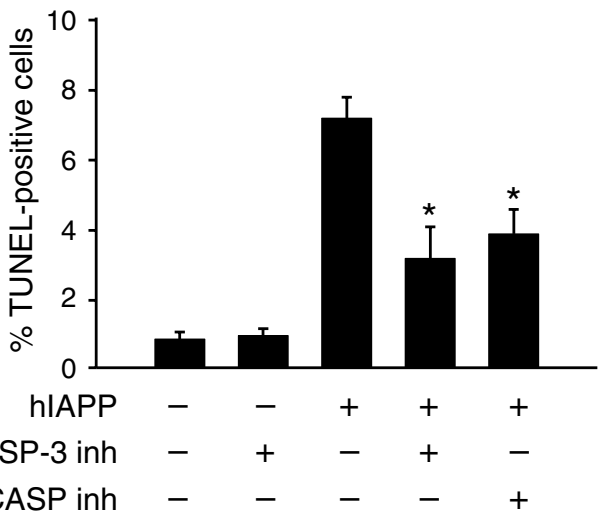

d

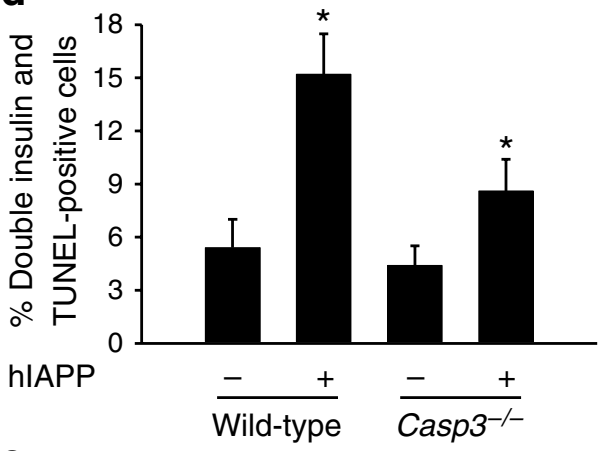

e

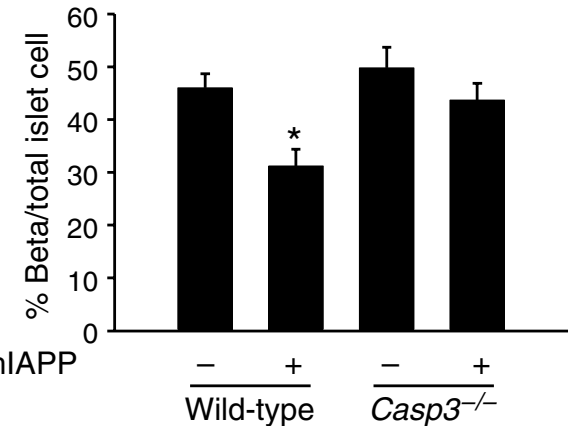

Fig. 3 Prevention of caspase-3 activation markedly reduces apoptosis in hIAPP-treated INS-1 and primary islet beta cells. INS-1 beta cells were cultured in the presence or absence of synthetic hIAPP $(10 \mu \mathrm{mol} / \mathrm{l})$ with or without a cell permeable caspase- 3 inhibitor $(100 \mu \mathrm{mol} / \mathrm{l})$ or a pan-caspase inhibitor $(100 \mu \mathrm{mol} / \mathrm{l})$ for 16 or $24 \mathrm{~h}$. Dispersed islet cells from wild-type and caspase-3 knockout mice were treated with hIAPP (10 $\mu \mathrm{mol} / \mathrm{l}, 24 \mathrm{~h})$. a Double immunostaining for insulin (red) and active caspase-3 (green; top panel; $16 \mathrm{~h}$ ) or insulin (green) and TUNEL (red; lower panel; $24 \mathrm{~h}$ ) of hIAPP-treated INS-1 beta cells cultured with or without caspase-3 inhibitor (CASP-3 inh). b Proportion of TUNELpositive hIAPP-treated cells cultured with or without the caspase-3 inhibitor (CASP-3 inh) or pan-caspase inhibitor (Pan CASP inh). c Double insulin (green) and TUNEL (red) staining of dispersed islet cells from wild-type and caspase-3 knockout mice following treatment with

examined whether prevention of amyloid-induced caspase3 activation and beta cell apoptosis enhances beta cell function in cultured hIAPP-expressing mouse islets. Following 7 day culture, islet insulin content and response to fibrillogenic hIAPP $(10 \mu \mathrm{mol} / 1,24 \mathrm{~h})$. Note the high number of double insulin- and TUNEL-positive cells (i.e. 1, 2, 3) in hIAPP-treated wildtype islet cells compared with caspase- 3 knockout islet cells. Proportion of TUNEL-positive beta cells (d) and beta cell/total islet cell ratio (e) in dispersed wild-type and caspase- 3 knockout mouse islet cells following treatment with hIAPP $(10 \mu \mathrm{mol} / \mathrm{l}, 24 \mathrm{~h})$. The proportion of apoptotic beta cells was quantified by counting double insulin- and TUNELpositive cells in a minimum of ten microscopic fields each of about 100-120 dispersed islet cells or 300-500 INS-1 cells. Beta/total islet cell ratio represents the mean of insulin-positive islet cells divided by total islet cells in each field. Results are means \pm SEM of three independent studies performed in triplicate. ${ }^{*} p<0.05$ vs control non-treated group (one-way ANOVA)

elevated glucose were reduced in hIAPP-expressing islets compared with wild-type islets (Fig. 4h, i). Insulin content and glucose response were increased by about $30 \%$ and $20 \%$, respectively, in cultured islets expressing hIAPP but 
lacking caspase-3, compared with those expressing hIAPP and caspase- 3 . The absence of caspase- 3 in islets expressing non-fibrillogenic mouse IAPP did not have any significant effect on insulin content or glucose response.

Amyloid formation in cultured human islets is associated with increased number of active caspase-3- and TUNELpositive beta cells To determine if fibrillogenesis of biosynthetic hIAPP in human islets is associated with caspase-3 activation, freshly isolated human islets were cultured in moderately high glucose (to potentiate amyloid formation) and then immunolabelled. There was no amyloid detectable in pre-culture islets by thioflavin $\mathrm{S}$ staining, but amyloid-positive islets were present following 7 days of culture (Fig. 5). Interestingly, most of the thioflavin S-positive islets had higher numbers of active caspase-3- and TUNEL-positive beta cells compared with thioflavin S-negative islets cultured under the same conditions (Fig. 5a). Furthermore, the majority of apoptotic cells in amyloid-positive islets were beta cells, with few detectable apoptotic alpha cells, leading to a decrease in islet beta/alpha cell ratio (Fig. 5b).

\section{Discussion}

Growing evidence suggests that hIAPP aggregates are toxic to beta cells and contribute to loss of beta cell mass in type 2 diabetes [3-5]. Furthermore, we have previously shown that amyloid formation in human [8] and hIAPP-expressing mouse islets [16] during culture is associated with beta cell death and that prevention of amyloid formation enhances survival and function of cultured islets $[8,16]$. The recent report of amyloid formation in human islets that had been transplanted into a type 1 diabetic patient [10] supports the idea that amyloid formation may also play a role in beta cell dysfunction/death in islet grafts. Accordingly, amyloid formation in hIAPP-expressing mouse islet grafts [9, 42] has been shown to result in recurrence of hyperglycaemia in diabetic mouse recipients [42]. Taken together, these findings suggest that amyloid formation may contribute to beta cell death through a similar mechanism in type 2 diabetes and in cultured and transplanted islets. The molecular mechanism(s) by which fibrillogenesis of endogenously produced hIAPP causes beta cell apoptosis are still not clear.

In this study we show, using two ex vivo models of islet amyloid formation, cultured human islets and hIAPPexpressing mouse islets lacking caspase- 3 , that caspase- 3 has a key role in beta cell apoptosis induced by fibrillogenesis of endogenously produced hIAPP in islets and that deletion of caspase- 3 protects islet beta cells from hIAPP aggregates formed during in situ islet culture. These findings provide direct evidence to support the hypothesis that aggregation of biosynthetic hIAPP produced by islet beta cells induces apoptosis, as least partially through activation of caspase-3. A key finding of our studies is that hIAPP, at concentrations found in islets in vivo such as type 2 diabetes and islet grafts, can induce activation of caspase-3.

Interestingly, our studies with both transformed and primary mouse islet cells revealed that alpha cells are markedly less susceptible to hIAPP toxicity than beta cells cultured under the same conditions. The finding that alpha cells survive much better than beta cells following exposure to hIAPP aggregates derived from both exogenously applied and endogenously produced hIAPP in cultured islets, suggests that the lower susceptibility of alpha cells to hIAPP toxicity cannot be explained solely by production of hIAPP by beta cells. Thus, other differences between alpha and beta cells appear to protect alpha cells from hIAPP aggregates in conditions associated with amyloid formation, such as culture, transplantation and type 2 diabetes. The particular susceptibility of beta cells to hIAPP may explain the selective beta cell death in type 2 diabetes.

Consistent with previous in vitro studies in transformed cell lines [25], we found that micromolar concentrations of synthetic hIAPP increases caspase-3 activation in INS-1 and primary islet beta cells. Furthermore, deletion of caspase- 3 in mouse islet cells markedly decreased the proportion of apoptotic beta cells following hIAPP treat-

Fig. 4 Deletion of caspase-3 in hIAPP-expressing mouse islets prevents beta cell apoptosis induced by fibrillogenesis of endogenously produced hIAPP and enhances beta cell function during culture. Islets isolated from wild-type, caspase-3 knock-out and hIAPP-transgenic mice expressing or lacking caspase-3 were cultured for 7 days. a Double insulin and caspase-3 immunostaining of pancreatic sections from wild-type and caspase- 3 knock-out mice. Left to right: insulin (red); caspase-3 (green); merge. b Double insulin (red) and thioflavin S (bright blue) staining of pancreatic sections from 12-month-old male hIAPP-transgenic mice with or without caspase-3 expression. c Islet sections of 7 day cultured islets from hIAPPtransgenic mice (8-16 weeks) expressing or lacking caspase-3 were double stained (top to bottom) for insulin (red) and thioflavin S (bright blue); insulin (red) and active caspase-3 (green); insulin (green) and TUNEL (red); glucagon (green) and TUNEL (red); or insulin (red) and glucagon (green). d Percentage of amyloid-positive islets assessed by double insulin and thioflavin S staining. Proportion of TUNELpositive beta cells (e), TUNEL-positive alpha cells (f), and islet beta cell/alpha cell ratio (g) were quantified following triple insulin/ TUNEL/DAPI or glucagon/TUNEL/DAPI staining. Islet insulin content (h) and glucose-stimulated insulin secretion (i) were measured by an ELISA specific for mouse insulin (ALPCO). The number of double insulin- (or glucagon-) and TUNEL-positive islet cells was counted in each islet in a total of 12-15 islets per condition. Islet beta cell/alpha cell ratio represents the mean of insulin-positive cells divided by glucagon-positive cells in each islet. Results are presented as the means $\pm \mathrm{SEM}$ of three independent experiments $(n=4 \mathrm{mice} /$ group, pooled islets). ${ }^{*} p<0.05$ vs wild-type group; ${ }^{\dagger} p<0.05$ vs corresponding caspase-3-expressing group (one-way ANOVA) 
ment. Taken together, these findings suggest that in both transformed and primary islet beta cells, exposure to aggregates derived from exogenously applied hIAPP induces caspase- 3 activation and that inhibition of caspase- 3 protects beta cells from exogenous hIAPP aggregates.
Amyloid fibrils are typically found extracellularly adjacent to beta cells in islets $[10,36,43]$. Intracellular amyloid-like aggregates have also been reported in human and hIAPP-overexpressing transgenic mouse islets transplanted into type 1 diabetic mice [4, 9, 44, 45]. Small a

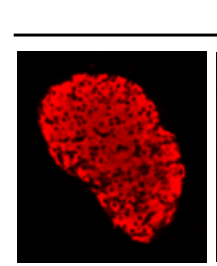

$\mathrm{Casp}^{+/+}$

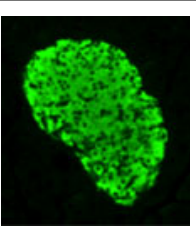

b

C
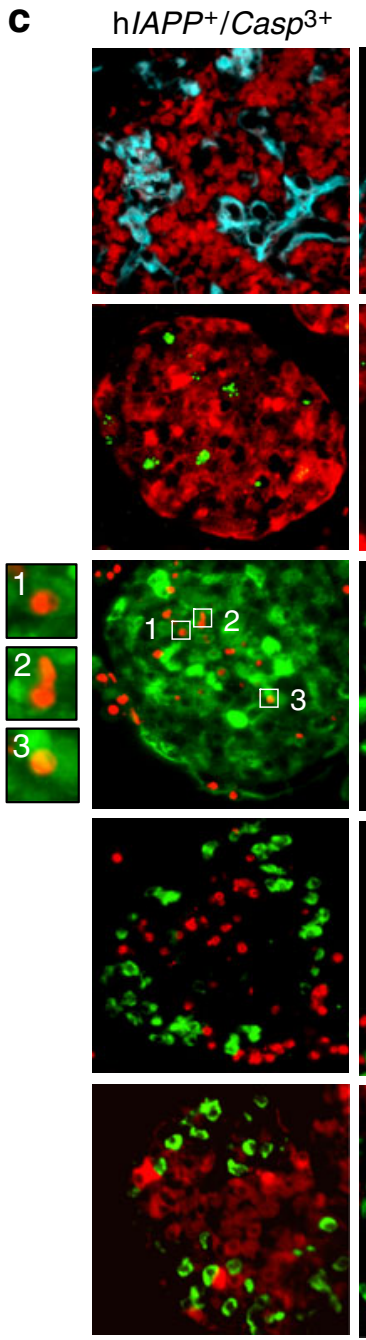
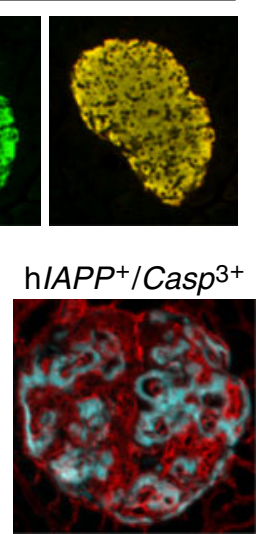

$\mathrm{h} / \mathrm{APP}^{+} / \mathrm{Casp}^{3+}$
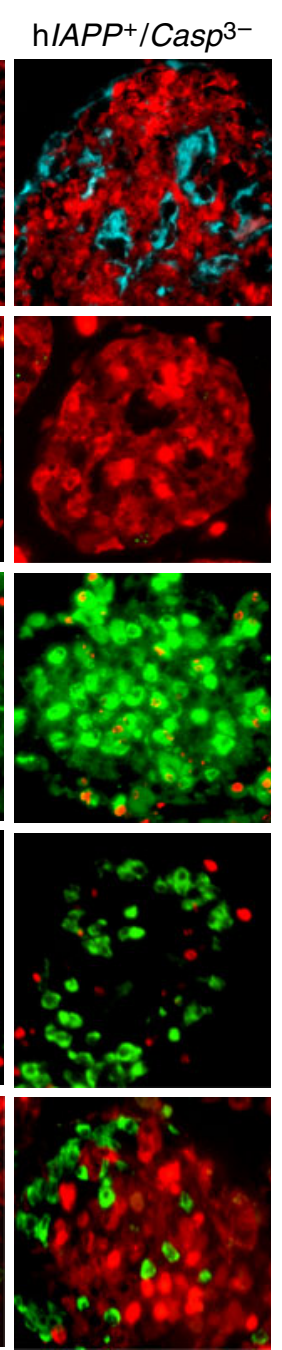

$\mathrm{Casp3}^{-/-}$
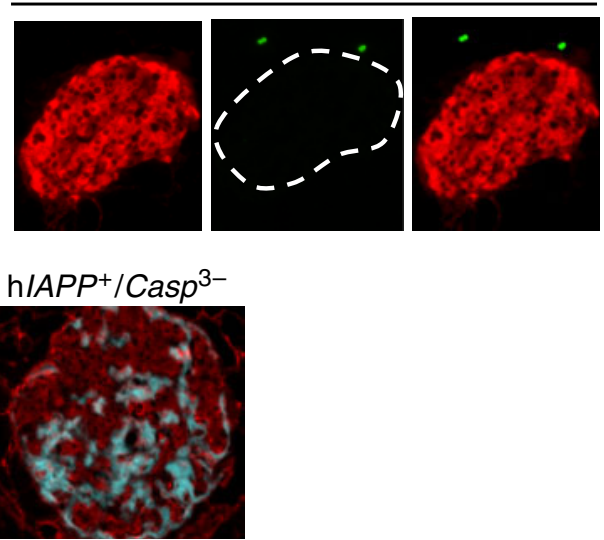

$\mathrm{h} / A P P^{-} /$Casp $^{3+}$

$\mathrm{h} / A P P^{-} /$Casp $^{3-}$
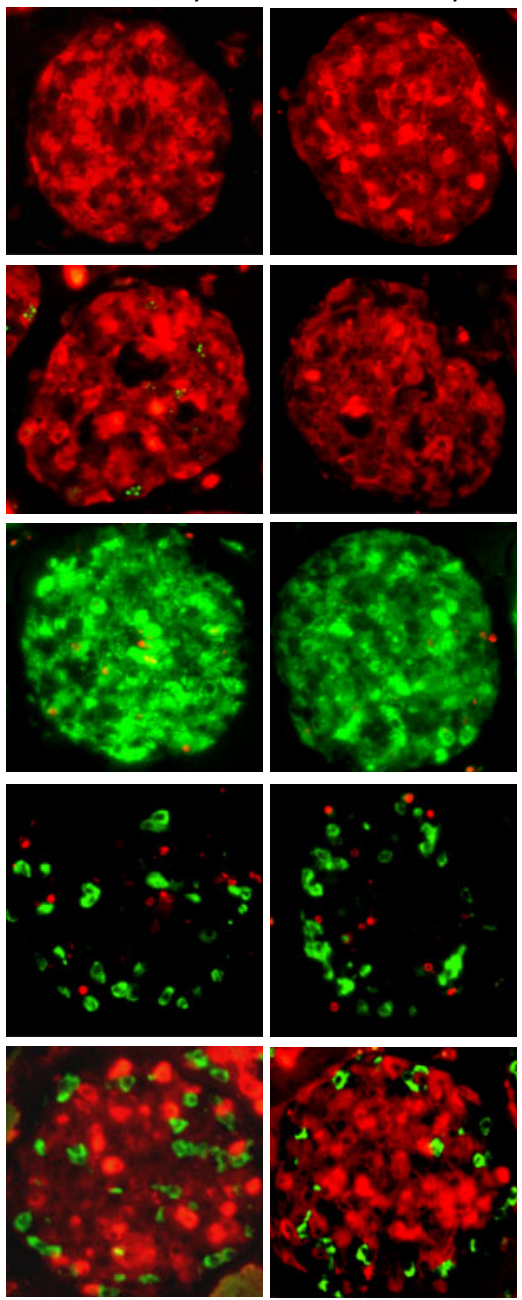
d

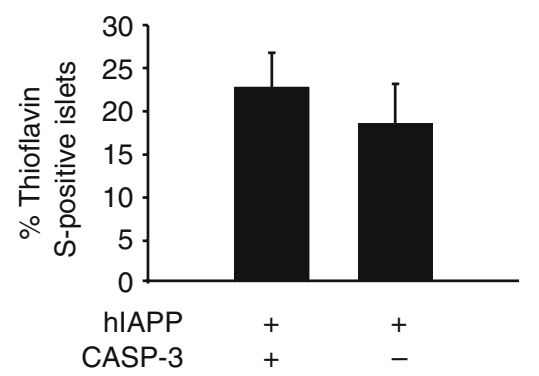

f

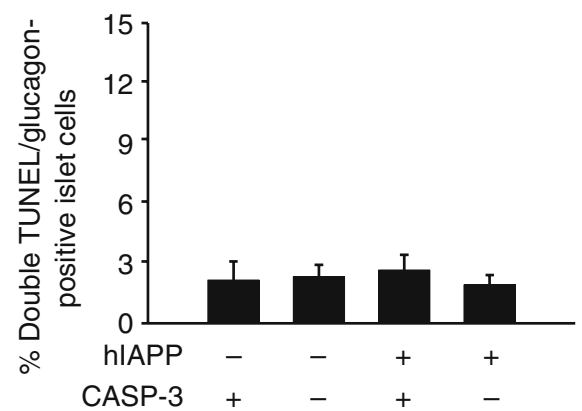

h

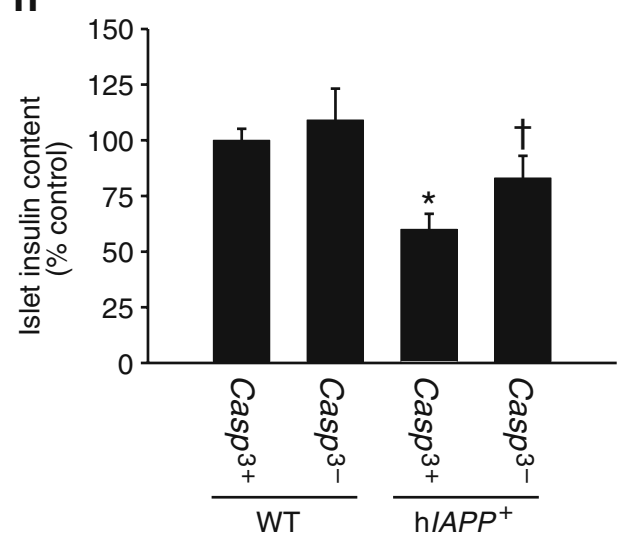

e

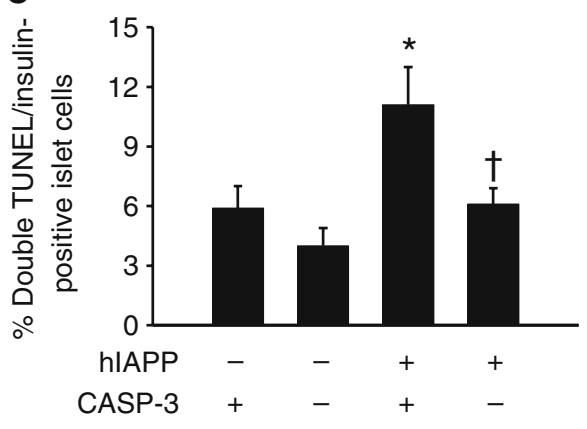

g

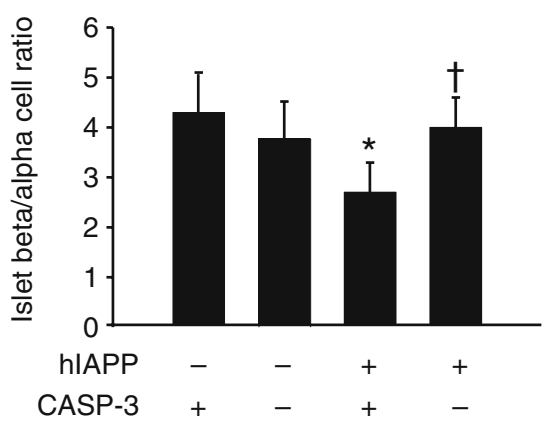

i

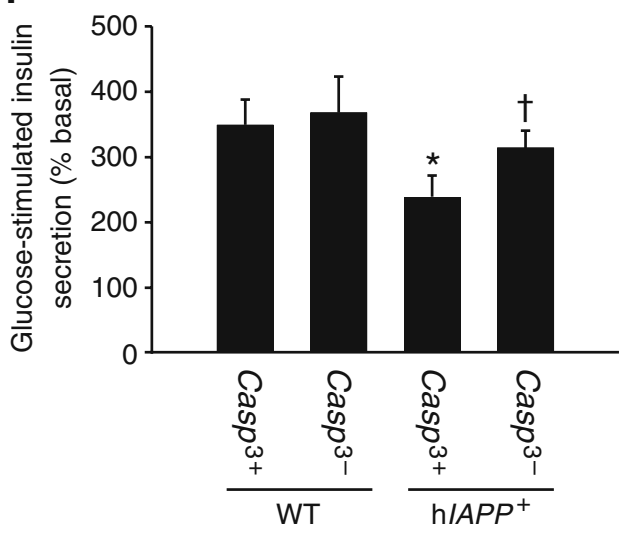

Fig. 4 (continued)

hIAPP aggregates appear to be more toxic than large fibrils and are probably the major mediators of beta cell death [19-21, 46]. Despite convincing evidence implicating a membrane interaction in the cytotoxicity of exogenous synthetic hIAPP aggregates [19, 46, 47], the mode of this interaction is still unclear. Our studies show that prevention of hIAPP aggregation and interaction with beta cells by the amyloid-binding dye Congo Red, markedly reduces caspase-3 activation and apoptosis in INS-1 beta cells, supporting the notion that interaction of extracellular hIAPP aggregates with beta cell membranes induces caspase- 3 activation and apoptosis. A recent study has demonstrated that exposure to synthetic hIAPP leads to upregulation of the cell membrane death receptor Fas in mouse islet beta cells in vitro [48], suggesting that hIAPP-induced beta cell apoptosis may involve activation of a Fas-mediated apoptotic pathway.

We generated a mouse model expressing hIAPP but lacking caspase- 3 to directly investigate the potential role of caspase-3 in mediating the toxic effects of endogenously produced hIAPP aggregates in islets. Islets from hIAPP-expressing mice with or without caspase-3 expression had comparable levels of amyloid formation both in vitro and in vivo, confirming that the absence of caspase-3 per se does not have any detectable effect on amyloid formation in hIAPP-expressing mouse islets. As expected [16, 49], hIAPP aggregates were not detectable in freshly isolated hIAPP-expressing mouse islets but were 
Fig. 5 Amyloid formation in cultured human islets is associated with increased number of active caspase-3- and TUNELpositive beta cells and reduced islet beta cell/alpha cell ratio. a Human islets were cultured in CMRL (11.1 mmol/1 glucose) for 7 days. Paraffin-embedded islet sections were double immunostained (left to right) for insulin (red) and amyloid (bright blue); insulin (red) and active caspase-3 (green); insulin (green) and TUNEL (red); and glucagon (green) and TUNEL (red). Note the higher number of active caspase-3- and TUNELpositive beta cells in thioflavin $\mathrm{S}$ (amyloid)-positive cultured islets (lower panel) compared with thioflavin S-negative islets (upper panel). b Islet beta cell/ alpha cell ratio was quantified in thioflavin S-positive and -negative islets. Results are expressed as means \pm SEM of five independent experiments performed in duplicate. * $p<0.05$ vs thioflavin S-negative group (Student's $t$ test)
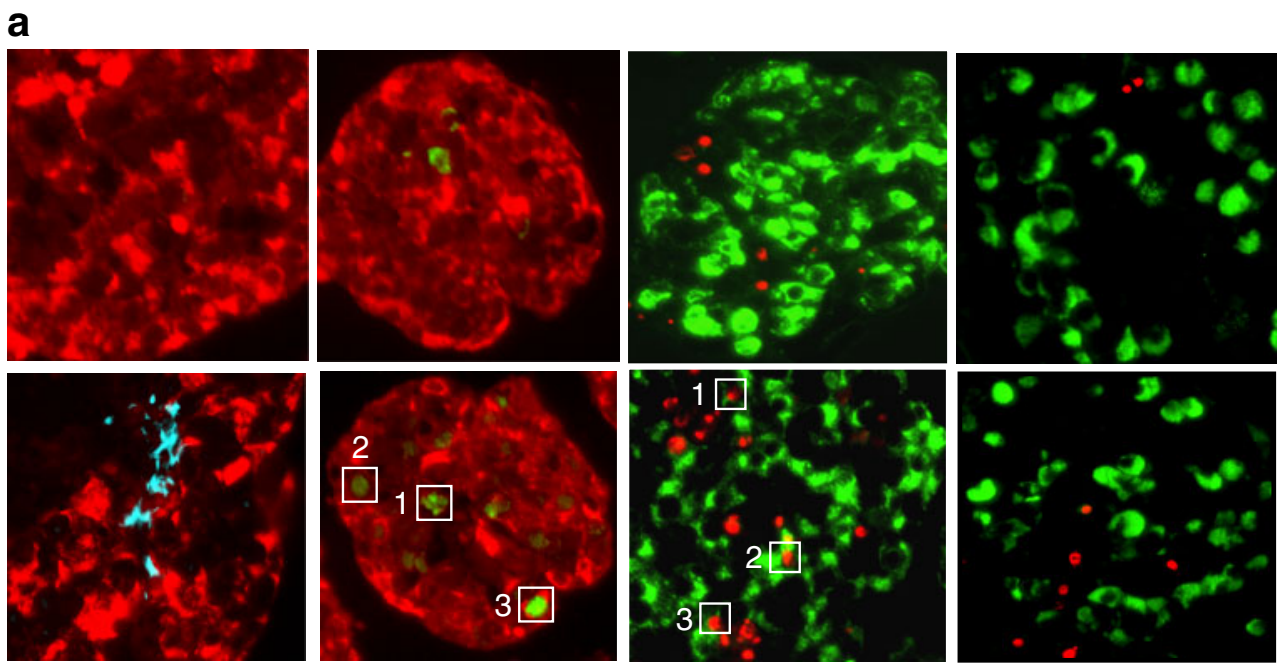

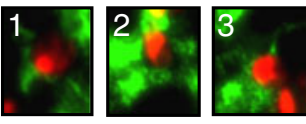

b

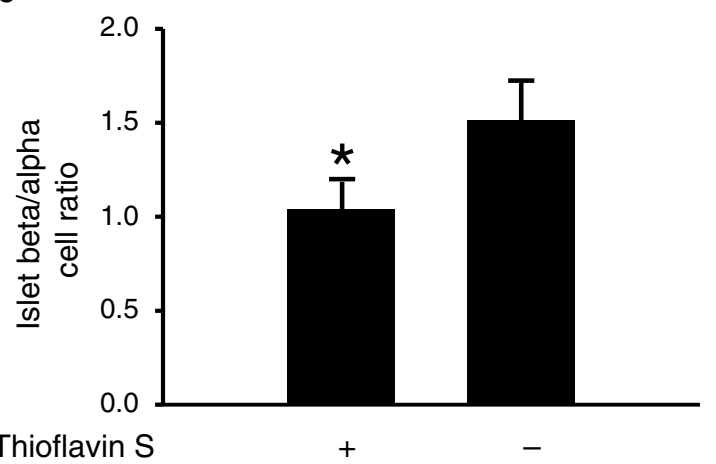

present in cultured islets. Interestingly, hIAPP-expressing islets lacking caspase- 3 had markedly lower apoptotic beta cells, higher insulin content and glucose response compared with islets expressing hIAPP and caspase-3, suggesting that deletion of caspase- 3 protects islet beta cells from endogenously produced hIAPP aggregates and improves their survival and function. Importantly, despite significant increase in the proportion of active caspase-3 and apoptotic beta cells, the number of apoptotic alpha cells was low in cultured hIAPP-transgenic mouse islets expressing or lacking caspase-3.

To further validate these findings, we used cultured human islets as an independent model of islet amyloid formation. Consistent with our previous findings [8], thioflavin S-positive hIAPP aggregates were detectable in some but not all cultured human islets. Interestingly, most of the amyloid-positive islets had a higher number of active caspase-3 and apoptotic beta cells compared with amyloidnegative islets cultured under the same conditions, suggesting that hIAPP aggregates and not culture conditions per se contribute to caspase-3 activation and beta cell apoptosis.
Despite amyloid formation, the number of apoptotic alpha cells was low in cultured human islets, leading to increased alpha/beta cell ratio. Less susceptibility of islet alpha cells to aggregates derived from biosynthetic hIAPP and selective amyloid-induced beta cell death may explain the increased islet alpha/beta cell ratio in conditions associated with islet amyloid formation. In support, amyloid formation associated with very low number of beta cells but high number of alpha cells was reported in the islet graft from a type 1 diabetic patient [10].

In summary, our studies show that inhibition of caspase-3 protects islet beta cells from the cytotoxic effects of endogenously secreted (and exogenously applied) hIAPP. Prevention of amyloid toxicity by short-term inhibition of caspase- 3 may provide a new approach to increase survival/function of human islets during pretransplant culture and possibly after transplantation. Finally, less susceptibility of alpha cells to hIAPP and selective amyloid-induced beta cell death may contribute to increased islet alpha/beta cell ratio in conditions associated with islet amyloid formation. 
Acknowledgements This work was supported by grants from the Canadian Institutes of Health Research to L. Marzban (MOP-81375) and M. Woo. Infrastructure support was provided by grants from the Canadian Foundation for Innovation (L. Marzban) and the Michael Smith Foundation for Health Research (MSFHR) to the Centre for Human Islet Transplantation and Beta-Cell Regeneration (G. L. Warnock). L. Marzban is a Scholar of the Canadian Diabetes Association and T. J. Kieffer is the recipient of a senior scholarship from the MSFHR. hIAPP-transgenic mice for these studies were kindly provided by S. Kahn (VA Puget Sound Health Care System, University of Washington, WA, USA). We gratefully acknowledge the outstanding technical assistance of M. Speck, I. Barta and A. Asadi in the completion of these studies.

\section{References}

1. Ahren B (2005) Type 2 diabetes, insulin secretion and beta-cell mass. Curr Mol Med 5:275-286

2. Butler AE, Janson J, Bonner-Weir S, Ritzel R, Rizza RA, Butler PC (2003) Beta-cell deficit and increased beta-cell apoptosis in humans with type 2 diabetes. Diabetes 52:102-110

3. Marzban L, Park K, Verchere CB (2003) Islet amyloid polypeptide and type 2 diabetes. Exp Gerontol 38:347-351

4. Haataja L, Gurlo T, Huang CJ, Butler PC (2008) Islet amyloid in type 2 diabetes, and the toxic oligomer hypothesis. Endocr Rev 29:303-316

5. Clark A, Nilsson MR (2004) Islet amyloid: a complication of islet dysfunction or an aetiological factor in type 2 diabetes? Diabetologia 47:157-169

6. Westermark P, Wernstedt C, Wilander E, Hayden DW, O'Brien TD, Johnson KH (1987) Amyloid fibrils in human insulinoma and islets of Langerhans of the diabetic cat are derived from a neuropeptide-like protein also present in normal islet cells. Proc Natl Acad Sci USA 84:3881-3885

7. Cooper GJ, Willis AC, Clark A, Turner RC, Sim RB, Reid KB (1987) Purification and characterization of a peptide from amyloid-rich pancreases of type 2 diabetic patients. Proc Natl Acad Sci USA 84:8628-8632

8. Marzban L, Tomas A, Becker TC et al (2008) Small interfering RNA-mediated suppression of proislet amyloid polypeptide expression inhibits islet amyloid formation and enhances survival of human islets in culture. Diabetes 57:3045-3055

9. Westermark G, Westermark P, Eizirik DL et al (1999) Differences in amyloid deposition in islets of transgenic mice expressing human islet amyloid polypeptide vs human islets implanted into nude mice. Metabolism 48:448-454

10. Westermark GT, Westermark P, Berne C, Korsgren O (2008) Widespread amyloid deposition in transplanted human pancreatic islets. N Engl J Med 359:977-979

11. Lukinius A, Wilander E, Westermark GT, Engstrom U, Westermark P (1989) Co-localization of islet amyloid polypeptide and insulin in the B cell secretory granules of the human pancreatic islets. Diabetologia 32:240-244

12. Kahn SE, D'Alessio DA, Schwartz MW et al (1990) Evidence of cosecretion of islet amyloid polypeptide and insulin by beta-cells. Diabetes 39:634-638

13. Marzban L, Trigo-Gonzalez G, Verchere CB (2005) Processing of pro-islet amyloid polypeptide in the constitutive and regulated secretory pathways of beta cells. Mol Endocrinol 19:2154-2163

14. Westermark P, Engstrom U, Johnson KH, Westermark GT, Betsholtz C (1990) Islet amyloid polypeptide: pinpointing amino acid residues linked to amyloid fibril formation. Proc Natl Acad Sci USA 87:5036-5040

15. Kahn SE, Andrikopoulos S, Verchere CB (1999) Islet amyloid: a long-recognized but underappreciated pathological feature of type 2 diabetes. Diabetes 48:241-253

16. Marzban L, Rhodes CJ, Steiner DF, Haataja L, Halban PA, Verchere CB (2006) Impaired $\mathrm{NH}_{2}$-terminal processing of human proislet amyloid polypeptide by the prohormone convertase $\mathrm{PC} 2$ leads to amyloid formation and cell death. Diabetes 55:2192-2201

17. Hou X, Ling Z, Quartier E et al (1999) Prolonged exposure of pancreatic beta cells to raised glucose concentrations results in increased cellular content of islet amyloid polypeptide precursors. Diabetologia 42:188-194

18. Paulsson JF, Westermark GT (2005) Aberrant processing of human proislet amyloid polypeptide results in increased amyloid formation. Diabetes 54:2117-2125

19. Janson J, Ashley RH, Harrison D, McIntyre S, Butler PC (1999) The mechanism of islet amyloid polypeptide toxicity is membrane disruption by intermediate-sized toxic amyloid particles. Diabetes 48:491-498

20. Demuro A, Mina E, Kayed R, Milton SC, Parker I, Glabe CG (2005) Calcium dysregulation and membrane disruption as a ubiquitous neurotoxic mechanism of soluble amyloid oligomers. J Biol Chem 280:17294-17300

21. Engel MF, Khemtemourian L, Kleijer CC et al (2008) Membrane damage by human islet amyloid polypeptide through fibril growth at the membrane. Proc Natl Acad Sci USA 105:6033-6038

22. Anguiano M, Nowak RJ, Lansbury PT Jr (2002) Protofibrillar islet amyloid polypeptide permeabilizes synthetic vesicles by a pore-like mechanism that may be relevant to type II diabetes. Biochemistry 41:11338-11343

23. Quist A, Doudevski I, Lin H et al (2005) Amyloid ion channels: a common structural link for protein-misfolding disease. Proc Natl Acad Sci USA 102:10427-10432

24. Rumora L, Hadzija M, Barisic K, Maysinger D, Grubiic TZ (2002) Amylin-induced cytotoxicity is associated with activation of caspase-3 and MAP kinases. Biol Chem 383:1751-1758

25. Zhang S, Liu J, Dragunow M, Cooper GJ (2003) Fibrillogenic amylin evokes islet beta-cell apoptosis through linked activation of a caspase cascade and JNK1. J Biol Chem 278:52810-52819

26. Young ID, Ailles L, Narindrasorasak S, Tan R, Kisilevsky R (1992) Localization of the basement membrane heparan sulfate proteoglycan in islet amyloid deposits in type II diabetes mellitus. Arch Pathol Lab Med 116:951-954

27. Park K, Verchere CB (2001) Identification of a heparin binding domain in the N-terminal cleavage site of pro-islet amyloid polypeptide. Implications for islet amyloid formation. J Biol Chem 276:16611-16616

28. Casas S, Novials A, Reimann F, Gomis R, Gribble FM (2008) Calcium elevation in mouse pancreatic beta cells evoked by extracellular human islet amyloid polypeptide involves activation of the mechanosensitive ion channel TRPV4. Diabetologia 51:2252-2262

29. Wong WP, Scott DW, Chuang CL et al (2008) Spontaneous diabetes in hemizygous human amylin transgenic mice that developed neither islet amyloid nor peripheral insulin resistance. Diabetes 57:2737-2744

30. Huang CJ, Lin CY, Haataja L et al (2007) High expression rates of human islet amyloid polypeptide induce endoplasmic reticulum stress mediated beta-cell apoptosis, a characteristic of humans with type 2 but not type 1 diabetes. Diabetes 56:2016-2027

31. Matveyenko AV, Gurlo T, Daval M, Butler AE, Butler PC (2009) Successful vs failed adaptation to high fat diet induced insulin resistance; the role of IAPP induced beta cell endoplasmic reticulum stress. Diabetes 58:906-916 
32. Zraika S, Hull RL, Udayasankar J et al (2009) Oxidative stress is induced by islet amyloid formation and time-dependently mediates amyloid-induced beta cell apoptosis. Diabetologia 52:626-635

33. Gloire G, Charlier E, Piette J (2008) Regulation of CD95/APO-1/ Fas-induced apoptosis by protein phosphatases. Biochem Pharmacol $76: 1451-1458$

34. Green DR (2005) Apoptotic pathways: ten minutes to dead. Cell $121: 671-674$

35. Welihinda AA, Tirasophon W, Kaufman RJ (1999) The cellular response to protein misfolding in the endoplasmic reticulum. Gene Expr 7:293-300

36. Verchere CB, D'Alessio DA, Palmiter RD et al (1996) Islet amyloid formation associated with hyperglycemia in transgenic mice with pancreatic beta cell expression of human islet amyloid polypeptide. Proc Natl Acad Sci USA 93:3492-3496

37. Woo M, Hakem R, Soengas MS et al (1998) Essential contribution of caspase 3/CPP32 to apoptosis and its associated nuclear changes. Genes Dev 12:806-819

38. Kuida K, Zheng TS, Na S et al (1996) Decreased apoptosis in the brain and premature lethality in CPP32-deficient mice. Nature 384:368-372

39. Liadis N, Murakami K, Eweida M et al (2005) Caspase-3dependent beta-cell apoptosis in the initiation of autoimmune diabetes mellitus. Mol Cell Biol 25:3620-3629

40. Lorenzo A, Razzaboni B, Weir GC, Yankner BA (1994) Pancreatic islet cell toxicity of amylin associated with type-2 diabetes mellitus. Nature 368:756-760

41. Saafi EL, Konarkowska B, Zhang S, Kistler J, Cooper GJ (2001) Ultrastructural evidence that apoptosis is the mechanism by which human amylin evokes death in RINm5F pancreatic islet beta-cells. Cell Biol Int 25:339-350

42. Udayasankar J, Kodama K, Hull RL et al (2009) Amyloid formation results in recurrence of hyperglycaemia following transplantation of human IAPP transgenic mouse islets. Diabetologia $52: 145-153$

43. Westermark P (1973) Fine structure of islets of Langerhans in insular amyloidosis. Virchows Arch A Pathol Anat 359:1-18

44. Paulsson JF, Andersson A, Westermark P, Westermark GT (2006) Intracellular amyloid-like deposits contain unprocessed pro-islet amyloid polypeptide (proIAPP) in beta cells of transgenic mice overexpressing the gene for human IAPP and transplanted human islets. Diabetologia 49:1237-1246

45. Westermark P, Eizirik DL, Pipeleers DG, Hellerstrom C, Andersson A (1995) Rapid deposition of amyloid in human islets transplanted into nude mice. Diabetologia 38:543-549

46. Ritzel RA, Meier JJ, Lin CY, Veldhuis JD, Butler PC (2007) Human islet amyloid polypeptide oligomers disrupt cell coupling, induce apoptosis, and impair insulin secretion in isolated human islets. Diabetes 56:65-71

47. Lorenzo A, Yankner BA (1994) Beta-amyloid neurotoxicity requires fibril formation and is inhibited by congo red. Proc Natl Acad Sci USA 91:12243-12247

48. Zhang S, Liu H, Yu H, Cooper GJ (2007) Fas-associated death receptor signaling evoked by human amylin in islet beta-cells. Diabetes 57:348-356

49. Zraika S, Hull RL, Udayasankar J et al (2007) Glucose- and timedependence of islet amyloid formation in vitro. Biochem Biophys Res Commun 354:234-239 